\title{
PENGARUH SCIENTIFIC INQUIRY TERHADAP HASIL BELAJAR BIOLOGI
}

\section{THE EFFECT OF SCIENTIFIC INQUIRY ON BIOLOGICAL LEARNING OUTCOMES}

\author{
Ndzani Latifatur Rofi'ah ${ }^{1)}$, Tutut Indria Permana ${ }^{2)}$ \\ ${ }^{1)}$ Pendidikan Biologi, Fakultas Sains dan Teknologi, Universitas Islam Negeri \\ Walisongo Semarang \\ ${ }^{2)}$ Pendidikan Biologi, Fakultas Keguruan dan Ilmu Pengetahuan, Universitas \\ Muhammadiyah Malang \\ e-mail: ndzani.latifatur@walisongo.ac.id
}

diterima : 2 Februari 2020; dipublikasi : 30 Maret 2020

DOI : 10.32528/bioma.v5i1.3686

\begin{abstract}
ABSTRAK
Proses pembelajaran biologi di kelas dapat dilakukan dengan pendekatan ilmiah melalui penyelidikan. Pembelajaran biologi seharusnya dilakukan dengan memberikan kesempatan pada siswa untuk terlibat secara aktif menggunakan keterampilan proses dalam menemukan konsep dari fenomena ilmiah dalam kehidupan sehari-hari. Penelitian ini bertujuan untuk mengetahui pengaruh scientific inquiry terhadap hasil belajar biologi. Penelitian eksperimen ini menggunakan nonrandomized control group pretest-posttest design. Populasi penelitian ini adalah siswa SMA di Malang, 32 siswa sebagai kelompok eksperimen dan 32 siswa sebagai kelompok kontrol. Instrumen penelitian berupa soal pretes-postes dan lembar observasi. Hasil belajar siswa dianalisis menggunakan analisis kovarian dan uji t. Hasil penelitian menunjukkan bahwa scientific inquiry secara signifikan meningkatkan hasil belajar biologi siswa.
\end{abstract}

Kata kunci : Inquiry, Hasil belajar, Biologi

\begin{abstract}
The learning process of biology in the classroom can be done with a scientific approach through investigation. Biology learning should be done by providing opportunities for students to be actively involved in using process skills in discovering concepts from scientific phenomena in everyday life. This study aims to determine the effect of scientific inquiry on biology learning outcomes. This experimental study used a nonrandomized control group pretest-posttest design. The population of this study were high school students in Malang, 32 students as the experimental group and 32 students as the control group. The research instrument was in the form of pretestposttest questions and observation sheets. Student learning outcomes were analyzed using covariance analysis and $t$ test. The results showed that scientific inquiry significantly improved student learning outcomes for biology.
\end{abstract}

Keywords : Inquiry, Learning Outcomes, Biology 


\section{PENDAHULUAN}

Kemajuan ilmu pengetahuan dan teknologi terjadi sangat cepat pada abad 21 (Osman et al., 2009). Kemajuan dalam ilmu pengetahuan dan teknologi membawa perubahan dalam kehidupan sehari-hari. Kita dihadapkan pada tuntutan akan pentingnya sumber daya manusia yang berkualitas serta mampu berkompetisi. Sumber daya manusia yang berkualitas, dihasilkan oleh pendidikan yang berkualitas dapat menjadi kekuatan utama untuk mengatasi masalah-masalah yang dihadapi. Ini dikarenakan pendidikan memegang peranan sangat penting dan strategis dalam membangun masyarakat berpengetahuan. Siswa perlu dibekali dengan keterampilan untuk menghadapi tantangan abad 21 agar mampu bersaing di era globalisasi (Turiman et al., 2012).

Proses pembelajaran biologi di kelas dapat dilakukan dengan pendekatan ilmiah. Berpikir ilmiah berkaitan dengan pembelajaran menggunakan metode ilmiah (Kemendikbud, 2014). Permendikbud No.65 tahun 2013 menyatakan bahwa untuk memperkuat pendekatan ilmiah (scientific), perlu diterapkan pembelajaran berbasis penemuan (inquiry learning). Salah satu model pembelajaran yang menggunakan metode ilmiah adalah inkuiri (eksplorasi ilmiah) (Llewellyn, 2013). Model pembelajaran ini meliputi kegiatan mengidentifikasi masalah, mengajukan hipotesis, mengidentifikasi variabel yang relevan, merancang eksperimen untuk menguji hipotesis, melakukan prosedur investigasi, mengumpulkan data berdasarkan eksperimen, mengubah data dalam bentuk tabel dan grafik, dan menarik kesimpulan (Germann, 1999; Llewellyn, 2013 ). Scientific Inquiry, guru hanya berperan untuk menyampaikan fenomena dan membawa siswa menuju ke topik yang akan dipelajari, kemudian siswa yang merancang prosedur investigasi, menganalisis data dan menyampaikan hasil investigasi (Llewellyn, 2013; Trna et al., 2012).

Pembelajaran scientific inquiry merupakan pembelajaran melalui penyelidikan ilmiah dimana siswa belajar bagaimana memecahkan masalah dan menyelidiki secara ilmiah yang memungkinkan siswa belajar mengenai kehidupan nyata dalam sains dan pengetahuan ilmiah dalam kehidupan (Lu et al., 2015). Hal ini bertujuan untuk mendorong kemampuan peserta didik untuk menghasilkan karya kontekstual, baik individual maupun kelompok. Inkuiri memfokuskan pada menggambarkan, 
menjelaskan, memprediksi, dan mengkomunikasikan fenomena ilmiah (Harrison \& Treagust, 2000). Kegiatan penyelidikan memberikan konteks berharga bagi peserta didik untuk memperoleh, mengklarifikasi, dan menerapkan pemahaman konsep sains. Proses berinkuiri di dalam kelas dapat dilakukan dalam beberapa hari, misalnya hari pertama siswa diajak untuk mengamati dan menyampaikan apa yang mereka ketahui tentang es, kemudian siswa diberi permasalahan dan diberi kesempatan untuk mendiskusikan langkah percobaan untuk menjawab permasalahan tersebut. Hari kedua siswa sudah berada di kelompoknya masing-masing dan memulai menulis langkah investigasi serta alat dan bahan yang diperlukan. Hari ketiga siswa memulai investigasi. Hari keempat siswa mengorganisasi data yang sudah diperoleh. Hari kelima siswa meyampaikan hasil investigasi mereka di hadapan teman-teman dalam bentuk tulisan di kertas yang lebar (Llewellyn, 2013).

Melalui proses inquiry, siswa memperoleh pengetahuan dengan membuat serangkaian penemuan dan pemecahan pertanyaan yang berbeda ( $\mathrm{Lu}$ et al., 2015). Melalui pembelajaran inkuiri siswa belajar memecahkan masalah karena siswa dilatih untuk menganalisis dan menangani informasi yang mereka peroleh (Nurhadi et al., 2009). Berdasarkan observasi yang dilakukan menunjukkan bahwa pembelajaran di kelas kurang menekankan pada proses ilmiah dan keterampilan proses. Pembelajaran biologi seharusnya dilakukan dengan memberikan kesempatan pada siswa untuk terlibat secara aktif dalam menemukan konsep dari fenomena ilmiah yang ditemukan dalam kehidupan sehari-hari (Yulaikah et al., 2015).

Inkuiri merupakan strategi pembelajaran yang efektif dalam membantu siswa untuk memahami konsep dan menggunakan keterampilan proses (Yager \& Akcay, 2010). Kegiatan penyelidikan memberikan konteks berharga bagi peserta didik untuk memperoleh, mengklarifikasi dan menerapkan pemahaman konsep sains. Dengan demikian penggunaan inquiry dalam pembelajaran dapat digunakan untuk meningkatkan hasil belajar siswa.

\section{METODE}

Penelitian ini menggunakan eksperimen semu (quasi experiment). Jenis eksperimen yang digunakan adalah nonrandomized control group pretest-posttest design (Leedy \& Ormrod, 2005). Subjek penelitian terdiri dari dua kelompok yaitu 
kelompok eksperimen dan kelompok kontrol. Hasil belajar siswa dianalisis menggunakan analisis kovarian dan uji t.

Tabel 1. Rancangan eksperimen

\begin{tabular}{cccc}
\hline Kelompok & Pretest & Perlakuan & Posttest \\
\hline Kelompok 1 & Obs & Tx & Obs \\
Kelompok 2 & Obs & - & Obs \\
\hline
\end{tabular}

Keterangan: Obs $=$ Observe, pengukuran variabel yang diamati melalui pretes dan postes;

$\mathrm{Tx}=$ Treatment, perlakuan yang diberikan pada salah satu kelompok perlakuan (Sumber: Leedy \& Ormrod, 2005: 227).

Penelitian ini menggunakan tiga tahapan pengumpulan data meliputi tahap persiapan, tahap pelaksanaan, dan tahap pelaporan. Kegiatan yang dilakukan pada tahap persiapan yaitu melakukan observasi ke sekolah, menyusun perangkat pembelajaran, menyusun instrumen penelitian, melakukan validasi. Kegiatan yang dilakukan pada tahap pelaksanaan yaitu melaksanakan pretes untuk mengetahui kemampuan awal siswa, pretes meliputi soal kognitif. Melaksanakan proses pembelajaran dengan menerapkan scientific inquiry pada kelas eksperimen dan pembelajaran dengan strategi konfirmasi (inkuiri level 0) pada kelas kontrol, melakukan observasi untuk mengetahui afektif dan psikomotor pada kelas eksperimen dan kelas kontrol, melaksanakan postes untuk hasil belajar kognitif. Kegiatan yang dilakukan pada tahap pelaporan adalah melakukan uji prasyarat melalui uji normalitas dan uji homogenitas data dan melakukan pengujian hipotesis menggunakan anakova dengan bantuan Software SPSS 22.0 for Windows.

\section{HASIL DAN PEMBAHASAN}

Indikator hasil belajar kognitif sesuai dengan indikator pencapaian kompetensi materi sistem respirasi, sistem ekskresi, dan sistem koordinasi. Strategi pembelajaran scientific inquiry secara signifikan meningkatkan hasil belajar kognitif siswa p $(0,00)<$ 0,05; (Tabel 2). 
Tabel 2. Uji Anacova Pengaruh Scientific Inquiry terhadap Hasil Belajar Kognitif Siswa

\begin{tabular}{cccccc}
\hline Source & $\begin{array}{c}\text { Type III Sum of } \\
\text { Squares }\end{array}$ & df & $\begin{array}{c}\text { Mean } \\
\text { Square }\end{array}$ & F & Sig. \\
\hline Corrected & $4505.162^{\mathrm{a}}$ & 2 & 2252.581 & 32.952 & .000 \\
Model & 4257.565 & 1 & 4257.565 & 62.283 & .000 \\
Intercept & 3205.109 & 1 & 3205.109 & 46.887 & .000 \\
Pretes & 2106.803 & 1 & 2106.803 & 30.820 & .000 \\
Perlakuan & 4306.595 & 63 & 68.359 & & \\
Error & 326636.000 & 66 & & & \\
Total & 8811.758 & 65 & & \\
Corrected Total & R Squared $=.511$ (Adjusted R Squared = .496)
\end{tabular}

Hasil uji lanjut dengan LSD menunjukkan bahwa nilai postes setelah diberi pembelajaran dengan scientific inquiry memiliki pengaruh paling signifikan terhadap hasil belajar kognitif siswa dengan rata-rata sebesar 73,97 (Tabel 3). Selisih rata-rata skor kognitif terkoreksi kelas eksperimen lebih tinggi 47,22\% bila dibandingkan kelas kontrol.

Tabel 3. Uji LSD Hasil Belajar Kognitif

\begin{tabular}{lcc}
\hline Nilai & Rerata & Notasi BNT \\
\hline Pretes kelas kontrol & 43,74 & $\mathrm{a}$ \\
Postes kelas kontrol & 65,09 & $\mathrm{~b}$ \\
Pretes kelas eksperimen & 40,28 & $\mathrm{a}$ \\
Postes kelas eksperimen & 73,97 & $\mathrm{c}$ \\
\hline
\end{tabular}

Observasi psikomotor meliputi mempersiapkan alat dan bahan, megikuti prosedur, pengumpulan data, keselamatan, dan kebersihan. Observasi psikomotor siswa menunjukkan bahwa psikomotor siswa yang diberi pembelajaran scientific inquiry pada materi sistem respirasi, sistem ekskresi, dan sistem koordinasi berturut-turut 76,6; 77,7; 77,9. Skor tersebut termasuk dalam kategori sangat baik. Afektif diperoleh melalui observasi. Observasi afektif meliputi sikap jujur, disiplin, tanggung jawab, peduli, santun, percaya diri, dan kerja sama. Hasil uji t menunjukkan bahwa p $(0,045)<0,05$ pada materi sistem respirasi, p $(0,029)<0,05$ pada materi sistem ekskresi, $\mathrm{p}(0,002)<$ 0,05 pada materi sistem koordinasi sehingga dapat disimpulkan scientific inquiry signifikan berpengaruh terhadap afektif siswa. 
Hasil belajar kognitif siswa yang memperoleh pembelajaran scientific inquiry mengalami peningkatan yang signifikan dibandingkan siswa pada kelas kontrol. Pada pembelajaran scientific inquiry, siswa melakukan investigasi dan aktivitas secara individual maupun kelompok. Melalui investigasi siswa mengeksplorasi pengetahuan secara langsung karena dalam tahap ini siswa melakukan pengamatan langsung dan dapat membangun pengetahuan secara langsung. Siswa mencoba untuk menjawab dan memecahkan masalah melalui partisipasi aktif dalam investigasi. Melalui pertanyaanpertanyaan mengembangkan keinginan siswa untuk menggali informasi lebih dalam yang tidak dapat dipecahkan pada saat pengamatan. Saat melakukan investigasi menggunakan berbagai keterampilan proses sains mulai dari mengamati, mengukur, menafsirkan, mengkomunikasikan. Melalui investigasi pengetahuan menjadi lebih bermakna dan permanen (Tatar \& Kuru, 2006). Aktivitas yang dilakukan saat pengamatan dapat meningkatkan pemahaman konseptual siswa, karena saat pengamatan semua organ indera siswa saling berhubungan (Turiman et al., 2012) seperti yang dilaporkan oleh Şimşek \& Kabapinar (2010), Lati et al., (2012), Bayram et al., (2013), Cervetti et al., (2012).

Pada pembelajaran scientific inquiry siswa belajar aktif melalui percobaan dan menggunakan keterampilan kognitif (Cigrik \& Ozkan, 2015) sehingga melalui pembelajaran scientific inquiry ini dapat meningkatkan hasil belajar kognitif siswa. Dengan demikian kegiatan yang dilakukan selama pembelajaran scientific inquiry meningkatkan hasil belajar kognitif siswa. Pada penelitian ini hasil belajar kognitif siswa memiliki rata-rata 73,97. Nilai ini dapat ditingkatkan lagi dengan menerapkan pembelajaran scientific inquiry secara berkelanjutan.

Hasil observasi penelitian menunjukkan bahwa rata-rata psikomotor siswa yang diberi pembelajaran scientific inquiry termasuk dalam kategori sangat baik. Saat melakukan praktikum siswa mempersiapkan alat dan bahan yang sesuai dengan yang diperlukan. Prosedur kerja juga dilakukan secara berurutan, mengikuti setiap langkah prosedur, dan mendiskusikan dengan teman sekelompok dalam memecahkan masalah. Siswa mengumpulkan data secara teliti sehingga mendapatkan data yang lengkap. Keselamatan kerja juga diperhatikan oleh siswa saat praktikum, namun masih perlu diingatkan saat pengamatan berlangsung. Siswa menggunakan prosedur pembersihan dengan tepat, sehingga alat yang digunakan kembali bersih dan tertata rapi. Melalui 
pembelajaran scientific inquiry siswa belajar aktif melalui percobaan, sehingga siswa terbiasa menggunakan keterampilan proses sains (Cigrik \& Ozkan, 2015) yang mampu meningkatkan penggunaan keterampilan psikomotor (Turiman et al., 2012). Oleh karena itu melalui pembelajaran scientific inquiry psikomotor siswa termasuk dalam kategori sangat baik.

Hasil uji t menunjukkan scientific inquiry signifikan berpengaruh terhadap afektif siswa. Pada pembelajaran scientific inquiry siswa bekerja dalam kelompok sehingga dapat membentuk suasana kelompok yang menyenangkan (Bayram et al., 2013). Selama bekerja dalam kelompok siswa dilatih untuk bertanggung jawab dalam menyelesaikan tugas yang menjadi tanggung jawabnya, berpartisipasi aktif dalam kerja kelompok. Siswa menjaga kebersihan alat dan kelas maupun laboratorium saat melakukan praktikum. Pembelajaran ini melatih siswa untuk disiplin dalam menyelesaikan dan mengumpulkan tugas tepat waktu serta menaati aturan dalam pelaksanaan praktikum.

Siswa membantu teman sekelompok maupun kelompok lain yang mengalami kesulitan. Saat presentasi terjadi diskusi antar siswa, dimana siswa menyampaikan pendapat, sanggahan, jawaban dengan kalimat yang baik dan santun serta tidak menyela pembicaraan saat diskusi. Hal ini juga melatih percaya diri siswa saat melakukan presentasi dan diskusi. Bekerja dalam kelompok melatih siswa untuk bekerja sama dengan anggota kelompok saat praktikum maupun diskusi. Kegiatan praktikum melatih siswa untuk menyampaikan data sesuai hasil pengamatan, sehingga siswa terlatih untuk bersikap jujur. Pembelajaran scientific inquiry menggunakan keterampilan proses sehingga dapat melatih siswa dalam proses berpikir dan sikap ilmiah (Turiman et al., 2012). Pembelajaran scientific inquiry membuat siswa lebih aktif, sehingga mengembangkan sikap positif seperti yang dilaporkan oleh Bilgin (2006). Dengan demikian kegiatan yang dilakukan selama pembelajaran scientific inquiry meningkatkan afektif siswa.

\section{KESIMPULAN DAN SARAN}

Scientific inquiry secara signifikan meningkatkan hasil belajar siswa. Peningkatan hasil belajar kognitif pada kelas eksperimen lebih tinggi dibandingkan pada kelas kontrol dengan nilai 47,22\%. Hasil observasi menunjukkan bahwa rata-rata 
psikomotor siswa yang diberi pembelajaran scientific inquiry termasuk dalam kategori sangat baik. Hasil uji t menunjukkan scientific inquiry signifikan berpengaruh terhadap afektif siswa. Scientific inquiry sebaiknya diterapkan secara berkelanjutan dalam pembelajaran biologi. Selain itu dengan penerapan strategi ini hal yang perlu dipecahkan yaitu melatih siswa untuk mengakses informasi dari berbagai sumber sehingga siswa bisa belajar mengevaluasi informasi sains dan menentukan kebenaran dari informasi yang dibaca.

\section{DAFTAR PUSTAKA}

Bayram, Z., Oskay, O.O., Erdem, E., Ozgur, S.D. \& Sen, S. (2013). Effect of Inquiry Based Learning Method On Students' Motivation. Procedia - Social and Behavioral Sciences, 106: 988-996.

Bilgin, B. (2006). The Effects Of Hands-on Activities Incorporating A Cooperative Learning Approach on Eight Grade Students' Science Process Skills And Attitudes Toward Science. Journal of Baltic Science Education, 1(9): 27-37.

Cervetti, G.N., Barber, J., Dorph, R., Pearson, P.D. \& Goldschmidt, P.G. (2012). The Impact of an Integrated Approach to Science and Literacy in Elementary School Classrooms. Journal Of Research In Science Teaching, 49(5): 631-658.

Cigrik, E. \& Ozkan, M. (2015). The Investigation of The Effect of Visiting Science Center on Scientific Process Skills. Procedia - Social and Behavioral Sciences, 197: 1312-1316.

Germann, P. J. (1999). Developing Science Process Skills Through Direct Inquiry. The American Biology Teacher, 53(4): 243-247.

Harrison, A.G. \& Treagust, D.F. 2000 . A Typology of School Science Models. International Journal of Science Education, 22(9): 1011-1026.

Lati, W. , Supasorn, S. \& Promarak, V. (2012). Enhancement Of Learning Achievement And Integrated Science Process Skills Using Science Inquiry Learning Activities Of Chemical Reaction Rates. Procedia - Social and Behavioral Sciences, 46: 4471-4475.

Leedy, P.D. \& Ormord, J,E. (2010). Practical Research: Planning and Design. 9th Edition. Upper Saddle River, New Jersey: Pearson, Merril Prentice Hall. 
Llewellyn, D. (2013). Teaching High School Science Through Inquiry and Argumentation. USA: Saga Publication.

Osman, K., Hamid, S. H. A. \& Hassan, A. (2009). Standard Setting : Inserting Domain Of The 21st Century Thinking Skills Into The Existing Science Curriculum In Malaysia. Procedia Social and Behavioral Sciences, 1: 2573-2577.

Şimşek, P. \& Kabapinar, F. (2010). The Effects Of Inquiry-Based Learning On Elementary Students' Conceptual Understanding Of Matter, Scientific Process Skills And Science Attitudes. Procedia Social and Behavioral Sciences, 2: 1190-1194.

Tatar. N. \& Kuru M. (2006). The Effect of Inquiry-Based Learning Approach in Science Education on Academic Achievement. Hacettepe Üniversitesi Ĕ̌itim Fakültesi Dergisi, 32(2): 147-158.

Trna, J., Trnova, E. \& Sibor, J. (2012). Implementation of Inquiry-Based Science Education In Science Teacher Training. Journal of Educational And Instructional Studies In The World, 2(4): 199-209.

Turiman, P., Omar, J., Daud, A.M. \& Osman, K. (2012). Fostering the 21st Century Skills Through Scientific Literacy and Science Process Skills. Procedia Social and Behavioral Sciences, 59: 110-116.

Peraturan Menteri Pendidikan dan Kebudayaan Nomor 65 Tahun 2013. (2013). Jakarta: Menteri Pendidikan dan Kebudayaan RI.

Nurhadi, Yasin, B. \& Senduk, A.G. (2009). Pembelajaran Kontekstual. Surabaya: JP Books.

Yager, R.E. \& Akçay, H. (2010). The Advantages of An Inquiry Approach For Science Instruction In Middle Grades. School Science \& Mathematics, 110: 5-12.

Yulaikah, S., Alfindasari, D. \& Adawiyah, R. (2015). Integrasi Scientific Inquiry dengan Kompetensi Profesional Guru Biologi pada Pembelajaran Biologi di Abad ke-21. Prosiding Seminar Nasional Pendidikan Biologi 2015: Peran Biologi dan Pendidikan Biologi dalam Menyiapkan Generasi Unggul dan Berdaya Saing Global. Malang. 